$\angle$ Research Square

\title{
Myocilin gene mutations: A cause of juvenile open-angle glaucoma in north India
}

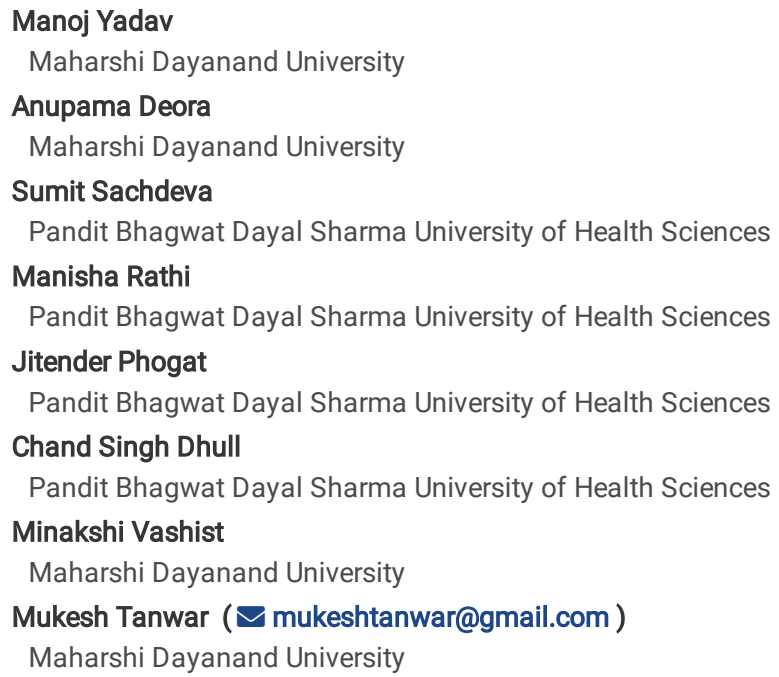




\section{Abstract \\ Purpose}

Juvenile-onset open-angle glaucoma (JOAG) is an uncommon type of primary open-angle glaucoma that affects individuals during childhood and early adulthood. Pathogenic variants in the myocilin gene account for varying frequencies of primary open-angle glaucoma and JOAG cases in different populations. This study has screened and identified novel and previously identified myocilin variants in a north Indian cohort of JOAG patients.

\section{Methods}

Eighty unrelated JOAG cases and one hundred controls have been screened for MYOC variants by PCR and DNA sequencing of exons.

\section{Results}

DNA sequencing revealed seventeen different variants. Out of these variants, five (p.G122A, p.R136I, p.S173T, p.K216I, and p.R200KTer*15) were novel and registered in NCBI. Pathogenic MYOC variants identified in $7.5 \%$ of JOAG cases.

\section{Conclusion}

Pathogenic myocilin variants account for $7.5 \%$ of cases of JOAG in our patient's cohort. This study augments the mutation spectrum of the MYOC gene, provides population-specific information, and aids in better understanding the underlying lesions of the disease.

\section{Introduction}

Glaucoma is a neurodegenerative disorder of the human eye responsible for a large number of blindness cases worldwide [1]. It may show a simple Mendelian pattern of inheritance in some familial cases [2]. Juvenile open-angle glaucoma (JOAG) is an uncommon type of glaucoma that affects individuals during childhood and early adulthood between 3-40 years of age [3]. Pathogenic myocilin (MYOC) variants account for 8\%-36 \% of cases of JOAG worldwide [4, 5]. Quigley and Broman (2006) have postulated that by the year 2020, around 89 million individuals will be affected and, approximately 6 million people bilaterally blind because of glaucoma [6]. A total of sixteen genetic loci have been associated with POAG cases by Genome-wide association studies. Pathogenic variants in MYOC, CYP1B1, OPTN and, WDR36 were reported to cause open-angle glaucoma [7-9]. Among these, MYOC was the first gene to be identified and responsible for POAG and JOAG phenotype in different populations $[4,10]$. Because the genetic causes of the JOAG vary in genetically distinct populations. This study was initiated to identify pathogenic MYOC variants and their frequency in a north-Indian cohort of JOAG Patients.

\section{Materials And Methods}

The study was approved by the Institutional Review Board of Pt. B.D. Sharma University of Health Sciences Rohtak (HR) India, and participating individuals or their guardians gave written informed consent consistent with the Declaration of Helsinki's tenets before the study. A total of eighty unrelated JOAG patients from the Glaucoma OPD facility of Regional Institute of Ophthalmology of the Pt. B.D. Sharma University of Health Sciences Rohtak were enrolled in this study. Patients are diagnosed to have JOAG if they met the following criteria " 1 ) elevated IOP>21 mmHg by Goldmann applanation tonometry at the initial hospital visit, 2) open-angle configuration on gonioscopy, and 3) glaucomatous optic neuropathy (neural rim thinning, focal notching or a vertical cup-to-disc ratio $>0.5$ ) and/or glaucomatous visual field defects." The age of onset age of disease in enrolled patients varied from 3 years to 40 years. ${ }^{[3]} \mathrm{A}$ total of hundred healthy individuals without any history of ocular and systemic disease enrolled as controls.

Exclusion Criterion: Cases of primary congenital glaucoma, traumatic glaucoma, and glaucoma with syndromes such as Axenfeld-Rieger syndrome/SturgeWeber syndrome are excluded in this study. Cases of developmental glaucomas with late presentations (patients with Haab's striae) were also excluded.

A five $\mathrm{ml}$ sample of venous blood was collected into EDTA vacutainer tubes (VACUETTE Greiner Bio-One) from patients and controls. Blood samples were stored at $-20^{\circ}$ Celsius until DNA isolation.

\section{Primer design}

A total of seven pairs of primers (Table 1) covering all exon and intron-exon junctions of MYOC (against reference sequence ENSG00000034971) were designed by using the primer design tool Primer3, available at https://www.ncbi.nlm.nih.gov/tools/primer-blast/

\section{DNA isolation, Polymerase Chain Reaction (PCR) and, DNA Sequencing}

DNA was isolated from all blood samples by using an established method [11]. All three exons and intron-exon junctions of $M Y O C$ were amplified by PCR using the primers detailed in Table 1, and products visualized on a 1.8\% agarose gel. PCR reactions performed in 40 $\mu$ l containing 100-150ng of genomic DNA with $4 \mu \mathrm{l}$ of $10 \mathrm{X}$ buffer, $2.0 \mu \mathrm{l}$ of $15 \mathrm{mM} \mathrm{MgCl} 2,2 \mu \mathrm{l}$ of dNTPs, $2 \mu \mathrm{l}$ of each primer and, $1 \mu \mathrm{l}$ of Taq DNA Polymerase (Genei Labs). During PCR, temperature profiles included initial denaturation at $94^{\circ} \mathrm{C}$ for 3 minutes followed by 35 cycles consisting of 30 seconds denaturation step at $94^{\circ} \mathrm{C}$, annealing at $54^{\circ}-60^{\circ} \mathrm{C}$ for 45-60 seconds and, extension at $72^{\circ} \mathrm{C}$ for $50-60$ seconds. After electrophoresis on a $1.8 \%$ agarose gel, amplified PCR products were purified using a PCR purification kit (Favorgen, Biotech Corp.) PurifiedPCR products were used for commercial DNA sequencing by Eurofins Genomics India Pvt Ltd. DNA 
sequences were compared to the ensemble MYOC reference sequence ENSG00000034971 using the CLUSTALW program. Identified sequence variants were confirmed by bidirectional sequencing and described as per latest HGVS recommendations and follow the universally accepted ACMG (American College of Medical Genetics) guidelines for characterizing a variant [12,13].

\section{Pathogenicity prediction of missense variants}

Identified missense variants were searched in ClinVar and gnomAd. The pathogenicity of identified missense sequence variants was predicted using SIFT ( Sorting Intolerant From Iolerant)[14]PROVEAN (Protein Variation Effect Analyzer)[15], PolyPhen2 [13,14,16] and Mutation Taster [3,17].

\section{Results}

A total of eleven missense variants, one frameshift variant and, five synonymous/neutral variants were identified in this study (Table 2)(chromatograms and pedigree included as supplement data). Variants identified in intron and untranslated regions (both $5^{\prime}$ and $3^{\prime}$ ) have not been considered. Details of all identified variants, associated amino acid variants, predictions of their pathogenicity (only for missense variants) and, other information is given in Table 3 . The variants identified included:

\section{1. p.Gln48His (g.171652468G>T):}

This variant is observed as a heterozygous variant in JOAG patient P28 but not observed in controls. This variant is present in ClinVar and gnomADv2.1.1 as a pathogenic variant.

\section{2. p.Arg76Lys (g.171652385G>A):}

This variant is observed as a homozygous variant in eleven JOAG patients and heterozygous variant in thirteen JOAG patients (Table 2). This variant is also observed in control samples. This variant is present in ClinVar and gnomAD v2.1.1 database with conflicting interpretations of pathogenicity.

\section{3. p.Gly122Ala (g.171652247G>C):}

This variant is observed as a homozygous variant in one JOAG patient (P12) but not observed in the control samples. This is a novel variant and has been registered in GenBank with accession no. MT126741

\section{4. p.Arg136lle (g.171652205G>T) :}

This variant is observed as a heterozygous variant in JOAG patient P13 but not observed in the control samples. This variant was found to be a novel and has been registered in GenBank with accession no. MT126742.

\section{5. p.Ser173Thr (g.171652094G>C):}

This variant was observed as a heterozygous variant JOAG patient P45, and not observed in control samples. This variant was also found to be a novel and registered in GenBank with accession no. MT126743.

\section{Compound heterozygous substitution/ p.[(Leu215Pro; Lys216lle)] (g.171607823T>C,g.171607822G>C, g.171607820A>T, g.171607819G>T):}

A compound heterozygous complex substitution was present in a JOAG patient P7 with a positive family history. This variant is also novel and has been registered in GenBank with accession no. MT126744. This variant is not observed in controls and databases.

\section{7. p.Ser238Asn (g.171638614G>A):}

This is observed as a homozygous variant in two JOAG patients (P24 and P36) but not observed in the control samples. This variant is not present in ClinVar and gnomADv2.1.1

\section{Pro370Leu (g.171605471C>T):}

This variant is identified in three JOAG patients (P5, P12, and P42). P5 had a positive history (in supplementary data) of the disease on her paternal side, but P12 and P42 were sporadic cases. This variant is present in ClinVar as a pathogenic variant.

\section{Arg422His (g.171636175G>A):}

This variant is observed as a heterozygous variant in one JOAG patient (P36) but not present in controls. This variant is present in gnomADv2.1.1 but absent in ClinVar.

\section{Frameshift mutation:}

One frameshift mutation p.Arg200Lysfs $\mathbf{1 5}$ also identified in the patient group. This mutation is predicted to produce a truncated myocilin protein of 214 amino acids with altered amino acids from position 200 to 214 due to the frameshift. This variant is identified as a homozygous change in JOAG patient P45 but is absent in controls. This variant is a novel mutation and has been registered in GenBank with accession no. MT126745.

Following five neutral sequence variants are also identified: 


\section{1. p.Glu14= (g. $171652570 G>A)$}

This variant is present as a heterozygote in three JOAG patients (P37, P38, and P39) but absent in controls. This variant is present in gnomADv2.1.1 as a synonymous variant.

\section{2. p.Lys156=(g.171652144G>A)}

This variant is present as a heterozygote in one JOAG patient P39 but absent in controls. This variant is not present in gnomADv2.1.1

\section{3. p.Tyr347= (g.171636399T>C)}

This variant is present as a heterozygote in one JOAG patient P67 but absent in controls. This variant is present in gnomADv2.1.1 as a benign synonymous variant.

\section{4 p.Phe430 $=(g .171636150 C>T)$}

This variant is present as a heterozygote in one JOAG patient P61 but absent in controls. This variant is present in gnomADv2.1.1 as a synonymous variant.

\section{4. $\mathrm{p}$. Lys484= $(\mathrm{g} .171635988 \mathrm{G}>\mathrm{A})$}

This is present as a homozygous variant in four JOAG patients (P26, P43, P47, P48) and a heterozygous variant in twenty-three JOAG patients (Table 2). This variant was also present in controls. This variant is present in gnomADv2.1.1 as a synonymous variant.

A total of $80 \mathrm{JOAG}$ patients and 100 controls individuals have been enrolled in the current study. Of the 80 patients, 27 were females, 53 were males, and the onset age of glaucoma varied from 5 years to 38 years. The most common presenting complaints were heaviness of the forehead and vision problems. DNA sequencing analysis identified pathogenic MYOC variants in six out of eighty (7.5\%) JOAG patients. Three patients of these six patients are positive for more than one sequence variant. These are as follows:

Patient P7 was a male with the onset of glaucoma at the age of 25 years. He had four heterozygous complex substitutions in which (g.171607823T>C (Heterozygous), g.171607822G $>C$ (Heterozygous), g.171607820A $>T$ (Heterozygous), g.171607819G $>T$ (Heterozygous) substituted by other bases. This variant produced codon $\mathrm{CTG}>\mathrm{CCC}$ and $\mathrm{AAG}>\mathrm{ATT}$, which resulted in the amino acid changes p.[(L215P; K216I)]. His IOP at diagnosis was 22mmHg in both eyes (Table 2). He was presented with a headache and diminished vision, having a cup/disc ratio of 0.9:1 in both eyes. He underwent glaucoma surgery for both eyes in 2013, 2014, and 2016. He currently has vision 3/60and, $1 / 60$ in the right and left eyes, respectively, and his current visual field is VF<10 ${ }^{0}$. One additional sibling of the proband has bilateral glaucoma, and his mother (now deceased) was also having glaucoma in both eyes. After multiple attempts, we could not get a blood sample from proband's brother and unable to confirm that he might be harbouring the same variants.

Patient P12 had compound heterozygous p.[(G122A; P370L)] mutations. Patient P12 was presented at 21 years of age with the heaviness of the forehead, vision problems, and redness of his eyes. He had IOP of 22 and $25 \mathrm{mmHg}$ in the right and left eyes in conjunction with a cup disc ratio of 0.9:1 in the right eye and $0.8: 1$ in the left eye, respectively. He has no vision in the right eye, and the vision in his left eye is $6 / 18$.

Patient P45 was a female who first presented in the ocular clinic at the age of 26 years. The patient had symptoms of vision loss, watering, and redness of her eyes. Her latest cup/disc ratio was $0.7: 1$ in both eyes with a vision of 6/36 in the right and 6/18 in the left eye, respectively. She had a deletion of guanine at genomic position g.171652013, predicted to result in p.R200Kfs*15, resulting in an abbreviated protein of 214 amino acids (Figure 1). Since this patient also harbours p.S173T variant, a truncated protein of 215 amino acids produced with threonine at position 173 and 14 novel amino acids (from $200-214$ ) will be different from wild type protein as a result of frameshift (shown in red color in Figure 1). This truncated protein might act as a mutated myocilin protein forming protein aggregates responsible for JOAG.

Patients P5 and P42 are heterozygous for already reported pathogenic p.P370L (g.171605471C>T) variant (Table 2). Patient P5 was a female, who presented at the ocular clinic with complaints of the heaviness of her forehead and vision loss at the age of 30 . She had an IOP of 26 and $34 \mathrm{mmHg}$ in the right and left eyes and optic cupping of 0.8:1 and 0.9:1 in the right and left eye, respectively. She had a vision of 6/18 in both eyes. She also underwent glaucoma surgery. Patient P42 was a male who presented at the ocular clinic at the age of 32 years with complaints of halos around light and scattered vision. He had IOPs of 28 and $22 \mathrm{mmHg}$ in the right and left eye, respectively with a cup disc ratio of $0.8: 1$ in both eyes. He had a vision of 6/36 in both eyes in his most recent clinical examination.

Patient P36 is harbouring p.R422H (g.171636175G >A) variant. She is presented to the ocular clinic at the age of 24 years with the complaints of the heaviness of her forehead, watering in both eyes, with vision problems. She had an IOP of $28 \mathrm{mmHg}$ in both eyes and visual acuities of $6 / 24$ and $6 / 60$ in the right and left eyes, respectively. The pathogenicity of $\mathrm{p} . \mathrm{R} 422 \mathrm{H}$ is uncertain because it shows an ambiguous pathogenicity prediction in which PolyPhen2 and Mutation taster predict it to be probably damaging and disease-causing. But it is predicted to be tolerated by SIFT and neutral by PROVEAN. Functional analysis of p.R422H mutation essentially required for a final verdict on its pathogenicity.

The presence of the p.Q48H (g.171652468G >T) mutation had already been observed in the JOAG/POAG/PCG cases in earlier glaucoma studies but never reported in controls [19-23].This variant lies in the N-terminal domain of the myocilin protein. A Triton-X-100 assay done using recombinant myocilin containing a histidine residue at the $48^{\text {th }}$ position showed protein aggregation, confirming the deleterious effect of the p.R48H variant [24]. The p.Arg76Lys reported as a non-pathogenic variant in earlier glaucoma studies $[19,25,26]$. The same message conveyed by its presence in both patients and controls in this study as well $[19,25,26]$. 
Myocilin variants predicted to be deleterious/pathogenic by all four programs are p.[(Leu215Pro;Lys216lle)] and p.Pro370Leu. The position of p.P370L lies in the C-terminal domain of myocilin. It has been reported as a disease-causing variant in several glaucoma studies. ${ }^{[30-32]}$ Transfection of human trabecular meshwork (TM) cells with the p.P370L myocilin mutant resulted in increased levels of endogenous reactive oxygen species (ROS and reduced ATP production, and increased cell death [18]. Sakai et al. (2007) reported that the myocilin protein enters into the mitochondria with a high molecular weight translocator complex in the outer and inner mitochondrial membranes and that myocilin mutations alter the protein structure and its confirmation [31,32]. The p.P370L mutation in the myocilin protein increases the mitochondria's sensitivity to various cellular injuries in the TM cells. It also disables normal TM cell functions and eventually contributes to the TM's failure to control IOP and glaucoma pathogenesis [18].

\section{Discussion}

GLC1A was the first locus to connect with primary open-angle glaucoma [33,34]. In 1997, pathogenic MYOC variants were identified as a cause of glaucoma, and these variants account for $8 \%-36 \%$ of cases of JOAG worldwide $[35,4,5]$. The myocilin gene encodes a $55 \mathrm{kDa}$ olfactomedin-related secretory protein with 504 amino acids [42]. In the human myocilin protein, the initial thirty-three amino acids form a signal peptide. Amino acids from 111 to 184 form an alphahelical coiled-coil region identical to the myosin tail fibre accommodating a leucine zipper pattern, which is involved in myocilin-myocilin interplay [43]. This leucine zipper section shows similarity to other known leucine zipper proteins. Myocilin shows homology to olfactomedin of bullfrogs, the $Z$ sector of a neuron-specific olfactomedin-related protein derived from rat brain and an express sequence tag (EST). Its olfactomedin-like motif in amino acids 246 to 504 contains beta-sheets with a disulfide bond connecting Cys245-Cys433 [43-45]. Cysteine is a well-preserved residue among all the myocilin proteins among different species and, it is well-maintained in olfactomedin and olfactomedin-like proteins throughout evolution [46]. It is a belief to be involved in protein oligomerization by disulfide-linkage in other olfactomedins. The linker section between 185 to 245 amino acids is pliable.

Comparative analysis of the amino acid sequences of myocilin protein from fifteen different species (Fig. 2 a \& 2 b) shows conservation of serine at 173 , leucine at 215 , lysine at 216 , proline at 370 , and arginine at 422 positions in all analyzed proteins. Glutamic acid at 48 and arginine at 136 also retained in $14 / 15$ species; glycine at 122 retained in 12/15 species studied. Simultaneously, arginine at 76 and serine at 238 was not conserved in most of the proteins analyzed. So p.R76K and p.S238N cannot be regarded as pathogenic variants.

Clinical phenotypes of patients with pathogenic myocilin variants were more severe than most JOAG patients negative for myocilin mutations. In the current study, we have identified pathogenic MYOC variants in $7.5 \%$ of cases. Similar findings have been reported by with Sripriya and associates in Indian POAG/JOAG population in 2004 [19].

The mutated myocilin protein is not secreted adequately from trabecular meshwork (TM) cells but retained in the cell bodies [47, 48]. This retained myocilin protein becomes cytotoxic to the cells, causes their death, leading to improper drainage. It causes an elevation in intraocular pressure, which is the most common risk factor for glaucomatous damage $[49,50]$.

Pathogenic myocilin variants may behave as a gain of function mutations and cause the glaucoma phenotype by hampering other ocular proteins' function $[47,51]$. They produce highly misfolded polypeptides and reduce secretion in cultured cells and transgenic mouse models [47, 51-54].

In 2001, Jacobson and associates transduced A549 and TM5 cells with wild-type and mutated MYOC adenovirus, including p.Q368X. In their study, the wild type myocilin protein was detected intracellularly as well as in the medium. But there was no detectable myocilin in the medium of A549 and TM5 cells transduced with p.Q368X adenovirus suggesting the possibility that the truncated myocilin protein may accumulate in intracellular compartments [47]. So, non-secreted mutant myocilin protein could compromise proteasomal function, leading to cell death [47, 51].

In 2008 Aroca-Aguilar and his team studied the heterozygous expression of wild-type and mutant myocilin proteins (p.E323K, p.R346T, p.P370L, p.D380A and p.Q368X) in HEK-293T cells and reported intracellular retention of wild-type myocilin and raised the extracellular concentration of mutant myocilin protein [55]. They observed extracellular mutant myocilin protein accounted for up to $20 \%$ of total mutated myocilin. The secreted wild type myocilin significantly decreased by 2.6 fold (for p.E323K) to 36 fold (for p.Q368X). All this might be due to specific structural defects in the protein, which could affect the formation of wild-type/mutant heteroaggregates. They suggested that the extracellular mutant myocilin in patients could be secreted by different tissues such as the ciliary muscle, ciliary epithelium and TM cells [56-58]. So, "heterozygous pathogenic variants in MYOC increase the secretion of the mutant forms and reduce the extracellular processed myocilin" [55]. This could also be due to a dominant-negative effect of pathogenic myocilin variants resulting from heteroaggregation and might contribute to the pathogenic mechanism leading to IOP rising and glaucoma. Similar findings (i.e. moderate elevation of IOP, loss of approximately $20 \%$ of retinal ganglion cells in the peripheral retina, and axonal degeneration in the optic nerve) have reported in the mouse [59].

Identifying new and already identified mutations in known glaucoma genes may enable us to design DNA based diagnostic tests in the near future. Besides, mutations in these genes should help us correctly identify the root cause of this devastating optic neuropathy. This, in turn, may enable us to diagnose the disease before the onset of irreversible vision loss. It also may give us critical information regarding future animal trial/testing with respect to drug response analysis.

\section{Conclusion}

Pathogenic myocilin variants identified in $7.5 \%$ of JOAG cases in north India. Five novel myocilin variants identified and registered in NCBI. This study augments the mutation spectrum of the MYOC gene, provides population-specific information, and aids in understanding the underlying lesions of glaucoma pathogenesis.

\section{Abbreviations}


JOAG: Juvenile open-angle glaucoma; MYOC: Myocilin; CYP1B1: Cytochrome P450 family 1 subfamily B member 1 ; OPTN: Optineurin ; WDR36: WD repeat domain 36; OPD: Outpatient Department; IOP: Intraocular pressure; NCBI: National Center for Biotechnology Information; TM: Trabecular meshwork; ATP:

Adenosine triphosphate; DNA: Deoxyribonucleic acid; EDTA: Ethylenediaminetetraacetic acid; PCR: Polymerase chain reaction; ${ }^{\circ} \mathrm{C}$ : degree Celsius; $\mu$ : microlitre;

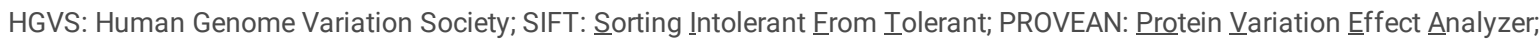

\section{Declarations}

\section{Authors Contributions:}

Manoj Yadav \& Anupama Deora have done the sample collection, benchwork and data analysis. Sumit Sachdeva, Manisha Rathi, and Jitender Phogat have provided patient samples and other details. Chand Singh Dhull conceptualized the study along with Mukesh Tanwar. Mukesh Tanwar also performed computational analysis. Minakshi Vashist and Mukesh Tanwar has written the manuscript. All authors read and finalized the manuscript.

\section{Funding:}

Indian Council of Medical Research, Govt. of India, via letter no. 5/4/6/07/Oph/14-NCD-II.

\section{Availability of data and materials}

MYOC reference sequence ENSG00000034971; CLUSTALW; ClinVar; gnomAd;

\section{Ethics approval and consent to participate}

The study was approved by the Institutional Review Board of Pt. B.D. Sharma University of Health Sciences Rohtak (HR) India, and participating individuals or their guardians gave written informed consent

\section{Consent for publication:}

Not Applicable. Patients' anonymity is strictly maintained.

\section{Competing Interests:}

The authors declare that they have no competing interests

\section{Author Details}

${ }^{1}$ Laboratory for Human Molecular Genetics, Department of Genetics, Maharshi Dayanand University, Rohtak (HR) India - 124001

${ }^{2}$ Regional Institute of Ophthalmology, Pt. B.D. Sharma University of Health Sciences, Rohtak (HR) India - 124001

${ }^{3}$ Human Molecular and Cytogenetic Laboratory, Department of Genetics, Maharshi Dayanand University, Rohtak (HR) India - 124001

\section{Acknowledgement}

The authors thank the patients and controls for their involvement in the study. The authors also thank the Indian Council of Medical Research, Govt. of India, to provide Financial Assistance. The author Mukesh Tanwar also expresses gratitude to Dr James Fielding Hejtmancik, OGVFB, National Eye Institute, National Institutes of Health, MD to interpret complex DNA sequence reads and manuscript editing.

\section{References}

1. Flaxman SR, Bourne RR, Resnikoff S, Ackland P, Braithwaite T, Cicinelli MV, et al. Global causes of blindness and distance vision impairment 1990-2020: a systematic review and meta-analysis. The Lancet Global Health. 2017 Dec 1;5(12):e1221-34.

2. Libby RT, Gould DB, Anderson MG, John SW. Complex genetics of glaucoma susceptibility. Annual review of genomics and human genetics. 2005 Aug $26 ; 6$.

3. Gupta V, Somarajan BI, Gupta S, Chaurasia AK, Kumar S, Dutta P, et al. The inheritance of juvenile onset primary open angle glaucoma. Clinical Genetics. 2017 Aug;92(2):134-42.

4. Yao YH, Wang YQ, Fang WF, Zhang L, Yang JH, Zhu YH. A recurrent G367R mutation in MYOC associated with juvenile open angle glaucoma in a large Chinese family. International journal of ophthalmology. 2018;11(3):369.

5. Wiggs JL, Allingham RR, Vollrath D, Jones KH, De La Paz M, Kern J, et al. Prevalence of mutations in TIGR/Myocilin in patients with adult and juvenile primary open-angle glaucoma. American journal of human genetics. 1998 Nov;63(5):1549.

6. Quigley HA, Broman AT: The number of people with glaucoma worldwide in 2010 and 2020. The British journal of ophthalmology 2006, $90: 262-267$

7. Sakurada Y, Mabuchi F. Genetic risk factors for glaucoma and exfoliation syndrome identified by genome-wide association studies. Current neuropharmacology. 2018 Aug 1;16(7):933 - 41.

8. Stone EM, Fingert JH, Alward WL, Nguyen TD, Polansky JR, Sunden SL, et al. Identification of a gene that causes primary open angle glaucoma. Science. 1997 Jan 31;275(5300):668-70. 
9. Yao YH, Zhu YH, Yang JH. Advances in genetics of primary open angle glaucoma. Chinese Journal of Experimental Ophthalmology. 2017;35(6):572-6.

10. Svidnicki PV, Braghini CA, Costa VP, Schimiti RB, de Vasconcellos JP, de Melo MB. Occurrence of MYOC and CYP1B1 variants in juvenile open angle glaucoma Brazilian patients. Ophthalmic genetics. 2018 Nov 2;39(6):717 - 24.

11. Sambrook J, Fritsch E F, Maniatus T. Molecular cloning: a laboratory manual, second ed., Cold Spring Harbour Labortory Press, 1989.

12. den Dunnen JT, Dalgleish R, Maglott DR, Hart RK, Greenblatt MS, McGowan-Jordan J, et al. HGVS recommendations for the description of sequence variants: 2016 update. Human mutation. 2016 Jun;37(6):564-9.

13. Richards S, Aziz N, Bale S, Bick D, Das S, Gastier-Foster J, et al. Standards and guidelines for the interpretation of sequence variants: a joint consensus recommendation of the American College of Medical Genetics and Genomics and the Association for Molecular Pathology. Genetics in medicine. 2015 May;17(5):405-23.

14. Tanwar M, Dada T, Sihota R, Yadav U, Das TK, Dada R. Mutation spectrum of CYP1B1 in North Indian congenital glaucoma patients. Mol Vis 2009;15:1200-1209 [PMID:19536304]

15. Choi Y. A fast computation of pairwise sequence alignment scores between a protein and a set of single-locus variants of another protein. In Proceedings of the ACM Conference on Bioinformatics, Computational Biology and Biomedicine 2012 Oct 7 (pp. 414-417).

16. Adzhubei IA, Schmidt S, Peshkin L, Ramensky VE, Gerasimova A, Bork P, et al. A method and server for predicting damaging missense mutations. Nat Methods. 2010;7:248-249

17. Schwarz JM, Cooper DN, Schuelke M, Seelow D. MutationTaster2: mutation prediction for the deep-sequencing age. Nat Methods. 2014 Apr;11(4):361-2

18. He Y, Leung KW, Zhuo YH, Ge J. Pro370Leu mutant myocilin impairs mitochondrial functions in human trabecular meshwork cells. Molecular Vision. 2009;15:815.

19. Sripriya S, Uthra S, Sangeetha R, George RJ, Hemamalini A, Paul PG, et al. Low frequency of myocilin mutations in Indian primary open-angle glaucoma patients. Clinical genetics. 2004 Apr;65(4):333-7.

20. Banerjee D, Bhattacharjee A, Ponda A, Sen A, Ray K. Comprehensive analysis of myocilin variants in east Indian POAG patients. Molecular vision. 2012;18:1548.

21. Rose R, Balakrishnan A, Muthusamy K, Arumugam P, Shanmugam S, Gopalswamy J. Myocilin mutations among POAG patients from two populations of Tamil Nadu, South India, a comparative analysis. Molecular vision. 2011;17:3243.

22. Kumar A, Basavaraj MG, Gupta SK, Qamar I, Ali AM, Bajaj V, et al. Role of CYP1B1, MYOC, OPTN and OPTC genes in adult-onset primary open-angle glaucoma: predominance of CYP1B1 mutations in Indian patients. Molecular vision. 2007;13:667.

23. Chakrabarti S, Kaur K, Komatireddy S, Acharya M, Devi KR, Mukhopadhyay A, et al. GIn48His is the prevalent myocilin mutation in primary open angle and primary congenital glaucoma phenotypes in India. Mol Vis. 2005 Feb 4;11:111-3.

24. Zhou Z, Vollrath D. A cellular assay distinguishes normal and mutant TIGR/myocilin protein. Hum Mol Genet 1999; 8:2221-8

25. Cheng JW, Cheng SW, Ma XY, Cai JP, Li Y, Lu GC, et al. Myocilin polymorphisms and primary open-angle glaucoma: a systematic review and metaanalysis. PloS one. 2012;7(9).

26. Xie X, Zhou X, Qu X, Wen J, Tian Y, Zheng F. Two novel myocilin mutations in a Chinese family with primary open-angle glaucoma. Molecular vision. 2008;14:1666.

27. Hamanaka T, Kimura M, Sakurai T, Ishida N, Yasuda J, Nagasaki M, et al. A histologic categorization of aqueous outflow routes in familial open-angle glaucoma and associations with mutations in the MYOC gene in Japanese patients. Investigative ophthalmology \& visual science. 2017 May 1;58(5):2818-31.

28. Qiu Y, Shen X, Shyam R, Yue BY, Ying H. Cellular processing of myocilin. PloS one. 2014;9(4).

29. Chen X, Yan N, Yun H, Sun J, Yu M, Zhou J, et al. Sequence analysis of MYOC and CYP1B1 in a Chinese pedigree of juvenile glaucoma with goniodysgenesis. Molecular vision. 2009;15:1530.

30. Zimmerman CC, Lingappa VR, Richards JE, Rozsa FW, Lichter PR, Polansky JR. A trabecular meshwork glucocorticoid response (TIGR) gene mutation affects translocational processing. Mol Vis. 1999 Aug 23;5:19.

31. Sakai H, Shen X, Koga T, Park BC, Noskina Y, Tibudan M, et al. Mitochondrial association of myocilin, product of a glaucoma gene, in human trabecular meshwork cells. Journal of cellular physiology. 2007 Dec;213(3):775-84.

32. Sundaresan P, Kanagavalli J, Pandaranayaka P, Krishnadas S, Krishnaswamy S. In vitro and in vivo Study on the Secretion of Gly367Arg Mutant Myocilin Protein. Investigative Ophthalmology \& Visual Science. 2007 May 10;48(13):5898-.

33. Sheffield VC, Stone EM, Alward WL, Drack AV, Johnson AT, Streb LM et al. Genetic linkage of familial open angle glaucoma to chromosome 1q21-q31. Nat Genet 1993; 4: 47-50.

34. Karali A, Russell P, Stefani FH, Tamm ER. Localization of myocilin/trabecular meshwork-inducible glucocorticoid response protein in the human eye. Investigative ophthalmology \& visual science. 2000 Mar 1;41(3):729 - 40.

35. Kubota R, Noda S, Wang Y, Minoshima S, Asakawa S, Kudoh J, et al. A novel myosin-like protein (myocilin) expressed in the connecting cilium of the photoreceptor: molecular cloning, tissue expression, and chromosomal mapping. Genomics. 1997 May 1;41(3):360-9

36. Fingert JH, Robin AL, Stone JL, Roos BR, Davis LK, Scheetz TE, et al. Copy number variations on chromosome $12 q 14$ in patients with normal tension glaucoma. Hum. Mol. Genet. 2011;20:2482-2494.

37. Braghini CA, Neshich IA, Neshich G, Soardi FC, de Mello MP, Costa VP, et al. New mutation in the myocilin gene segregates with juvenile-onset open-angle glaucoma in a Brazilian family. Gene. 2013 Jul 1;523(1):50 - 7.

Page $7 / 13$ 
38. Wei YT, Li YQ, Bai YJ, Wang M, Chen JH, Ge J, et al. Pro370Leu myocilin mutation in a Chinese pedigree with juvenile-onset open angle glaucoma. Molecular vision. 2011;17:1449.

39. Zhou Y, Grinchuk O, Tomarev SI. Transgenic mice expressing the Tyr437His mutant of human myocilin protein develop glaucoma. Invest Ophthalmol Vis Sci 2008; 49:1932-9.

40. Waryah AM, Narsani AK, Sheikh SA, Shaikh H, Shahani MY. The novel heterozygous Thr377Arg MYOC mutation causes severe Juvenile Open Angle Glaucoma in a large Pakistani family. Gene. 2013 Oct 10;528(2):356-9. doi: 10.1016/j.gene.2013.07.016. Epub 2013 Jul 23.

41. Wiggs JL, Lynch S, Ynagi G, Maselli M, Auguste J, Del Bono EA, et al. A genomewide scan identifies novel early-onset primary open-angle glaucoma loci on 9q22 and 20p12. The American Journal of Human Genetics. 2004 Jun 1;74(6):1314-20.

42. Nguyen TD, Chen P, Huang WD, Chen H, Johnson D, Polansky JR. Gene structure and properties of TIGR, an Olfactomedin-related Glycoprotein cloned from Glucocorticoid-induced Trabecular meshwork cells. The J Biol Sci., 1998, 11, 6341-50. PMID: 9497363

43. Yokoe h, Anholt RR. Molecular cloning of olfactomedin, an extracellular matrix protein specific to olfactory neuroepithelium. Proc Natl Acad Sci. 1993;90:4655-59. PMID: 8506313

44. Danielson PE, Forss-Petter S, Battenberg EL, de Lecea L, Bloom FE, Sutcliffe JG. Four structurally distinct neuron-specific olfactomedin-related glycoproteins produced by differential promoter utilization and alternative mRNA splicing from a single gene. J Neurosci Res. 1994;38:468-478. PMID: 7932877

45. Fautsch MP, Johnson DH. Characterization of myocilin-myocilin interactions. Invest. Ophthalmol. Vis. Sci 2001;42:2324-31. PMID: 11527946

46. Mukhopadhyay A, Gupta A, Mukherjee S, Chaudhuri K, Ray K. Did myocilin evolve from two different primordial proteins? Mol Vis 2002; 8:271-79. PMID: 12142865

47. Jacobson N, Andrews M, Shepard AR, Nishimura D, Searby C, Fingert JH, et al. Non-secretion of mutant proteins of the glaucoma gene myocilin in cultured trabecular meshwork cells and in aqueous humor. Human molecular genetics. 2001 Jan 15;10(2):117 - 25.

48. Liu Y, Vollrath D. Reversal of mutant myocilin non-secretion and cell killing: implications for glaucoma. Human molecular genetics. 2004 Apr 6;13(11):1193- 204.

49. Coleman AL, Kodjebacheva G. Risk factors for glaucoma needing more attention. The open ophthalmology journal. 2009;3:38.

50. Wiggs JL, Vollrath D. Molecular and clinical evaluation of a patient hemizygous for TIGR/MYOC. Archives of ophthalmology. 2001 Nov 1;119(11):1674-8.

51. Joe MK, Sohn S, Hur W, Moon Y, Choi YR, Kee C. Accumulation of mutant myocilins in ER leads to ER stress and potential cytotoxicity in human trabecular meshwork cells. Biochem Biophys Res Commun 2003; 312:592-600

52. Gobeil S, Letartre L, Raymond V. Functional analysis of the glaucoma-causing TIGR/myocilin protein: integrity of amino-terminal coiled-coil regions and olfactomedin homology domain is essential for extracellular adhesion and secretion. Exp Eye Res 2006; 82:1017-29

53. Zhuo YH, Wei YT, Bai YJ, Duan S, Lin MK, Saragovi HU, et al. Pro370Leu MYOC gene mutation in a large Chinese family with juvenile-onset open angle glaucoma: correlation between genotype and phenotype. Molecular vision. 2008;14:1533.

54. Zhuo YH, Mei W, Wei YT, Huang YL, Jian G. analysis of myoc gene mutation in a Chinese glaucoma family with primary open-angle glaucoma and primary congenital glaucoma. Chinese medical journal. 2006 Jul 1;119(14):1210-4.

55. Aroca-Aguilar JD, Sánchez-Sánchez F, Martínez-Redondo F, Coca-Prados M, Escribano J. Heterozygous expression of myocilin glaucoma mutants increases secretion of the mutant forms and reduces extracellular processed myocilin. Molecular Vision. 2008;14:2097.

56. Huang W, Jaroszewski J, Ortego J, Escribano J, Coca-Prados M. Expression of the TIGR gene in the iris, ciliary body, and trabecular meshwork of the human eye. Ophthalmic genetics. 2000 Jan 1;21(3):155 - 69.

57. Polansky JR, Fauss DJ, Chen P, Chen H, Lütjen-Drecoll E, Johnson D, et al. Cellular pharmacology and molecular biology of the trabecular meshwork inducible glucocorticoid response gene product. Ophthalmologica. 1997;211(3):126-39.

58. Swiderski RE, Ross JL, Fingert JH, Clark AF, Alward WL, Stone EM, et al. Localization of MYOC transcripts in human eye and optic nerve by in situ hybridization. Investigative ophthalmology \& visual science. 2000 Oct 1;41(11):3420-8.

59. Senatorov V, Malyukova I, Fariss R, Wawrousek EF, Swaminathan S, Sharan SK, et al. Expression of mutated mouse myocilin induces open-angle glaucoma in transgenic mice. Journal of Neuroscience. 2006 Nov 15;26(46):11903-14.

\section{Tables}

Table 1: Showing MYOC Primers Sequence (5'-3') 


\begin{tabular}{|c|c|c|c|}
\hline S.No. & Primer Name & Primer Sequence & Product Size in basepairs \\
\hline 1 & MYC1.1F & $5^{\prime}$ TATTTTCTAAGAATCTTGCTGGCAG $3^{\prime}$ & \multirow[t]{2}{*}{$394 \mathrm{bp}$} \\
\hline 2 & MYC1.1R & 5’ TGGATTCATTGGGACTGGC 3' & \\
\hline 3 & MYC1.2F & 5' AAGCCTCACCAAGCCTCTG 3' & \multirow[t]{2}{*}{$341 \mathrm{bp}$} \\
\hline 4 & MYC1.2R & 5' GCCTGGTCCAAGGTCAATT 3' & \\
\hline 5 & MYC1.3F & $\begin{array}{l}5^{\prime} \text { CTGGAGGCCACCAAAGCT 3' } \\
\end{array}$ & \multirow[t]{2}{*}{$448 \mathrm{bp}$} \\
\hline 6 & MYC1.3R & 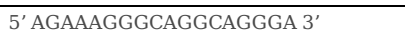 & \\
\hline 7 & MYC2F & 5' CATAGTCAATCCTTGGGCCA 3' & \multirow[t]{2}{*}{$381 \mathrm{bp}$} \\
\hline 8 & MYC2R & 5' CTGCAGACCTGCTCTGACAAG 3' $^{\prime}$ & \\
\hline 9 & MYC3.1F & $\begin{array}{l}5^{\prime} \text { TCTGAATTTACCAGGATGTGGAG 3' } \\
\end{array}$ & \multirow[t]{2}{*}{424 bp } \\
\hline 10 & MYC3.1R & 5' GTCAATGTCCGTGTAGCCAC 3' & \\
\hline 11 & MYC3.2F & 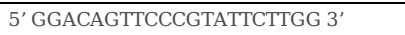 & \multirow[t]{2}{*}{$430 \mathrm{bp}$} \\
\hline 12 & MYC3.2R & 5' GCTTGGAGGCTTTTCACATC 3' & \\
\hline 13 & MYC3.3F & $\begin{array}{l}5^{\prime} \text { CAAGACCCTGACCATCCCA 3' } \\
\end{array}$ & \multirow[t]{2}{*}{$411 \mathrm{bp}$} \\
\hline 14 & MYC3.3R & $\begin{array}{l}5^{\prime} \text { GCCCCAAATCACAAGAAAAC 3' } \\
3^{\prime}\end{array}$ & \\
\hline
\end{tabular}

Table 2: Showing clinical phenotypes and MYOC nucleotide variants identified in this study 


\begin{tabular}{|c|c|c|c|c|c|}
\hline $\begin{array}{l}\text { Patient } \\
\text { ID }\end{array}$ & Presenting Complaint & $\begin{array}{c}\text { IOP in mm Hg at } \\
\text { presentation } \\
(\mathrm{Rt} / \mathrm{Lt})\end{array}$ & $\begin{array}{l}\text { Current Optical Cupping } \\
\text { (Rt/Lt) }\end{array}$ & $\begin{array}{l}\text { Current } \\
\text { Vision } \\
\text { (Rt ; Lt) }\end{array}$ & $\begin{array}{c}\text { Identified Variants } \\
\text { (H: homozygous; h:heterozygous) }\end{array}$ \\
\hline P1 & $\begin{array}{l}\text { Heaviness of Forehead, halos around lights, Watering in the } \\
\text { eyes }\end{array}$ & $25 / 18$ & $0.6: 1 / 0.5: 1$ & $6 / 6 / ; 6 / 6$ & -- \\
\hline $\mathrm{P} 2$ & Heaviness of Forehead, redness of eyes & $27 / 17$ & $0.7: 1 / 0.5: 1$ & $6 / 36 ; 6 / 6$ & p.R76K (H) \\
\hline P3 & Blurring of vision & $28 / 16$ & $0.6: 1 / 0.5: 1$ & $6 / 18 ; 6 / 12$ & p.R76K (H) \\
\hline $\mathrm{P} 4$ & Blurring of vision & $14 / 24$ & $0.5: 1 / 0.9: 1$ & $6 / 6 ; 6 / 12$ & -- \\
\hline P5 & Heaviness of Forehead, Vision problem & $26 / 34$ & $0.8: 1 / 0.9: 1$ & $6 / 18 ; 6 / 18$ & p.P370L (h) \\
\hline P6 & Blurring of vision & $21 / 23$ & $0.7: 1 / 0.7: 1$ & $6 / 18 ; 6 / 18$ & -- \\
\hline P7 & Headache, severe Vision loss day by day & $20 / 18$ & $0.9: 1 / 0.9: 1$ & $\begin{array}{l}3 / 60 ; 1 / 60 \\
\mathrm{VF}<10^{0}\end{array}$ & p.[(Leu215Pro; Lys216Пe)] (h) \\
\hline P8 & Pain in eyes & $22 / 21$ & $0.4: 1 / 0.7: 1$ & $6 / 6 ; 6 / 6$ & -- \\
\hline P9 & Heaviness of Forehead, sudden vision problems during night & $25 / 24$ & $0.6: 1 / 0.6: 1$ & $6 / 6 ; 6 / 9$ & p.R76K $(\mathrm{H})$ \\
\hline $\mathrm{P} 10$ & Redness of eyes, Vision Loss & $33 / 33$ & $0.8: 1 / 0.4: 1$ & $\mathrm{HM} ; 5 / 60$ & p.R76K $(\mathrm{h})$ \\
\hline P11 & Low vision, watering in eyes, heaviness of forehead & $22 / 22$ & $0.8: 1 / 0.7: 1$ & $6 / 60 ; 6 / 36$ & \\
\hline P12 & $\begin{array}{l}\text { Heaviness of Forehead, halos around light with vision } \\
\text { problems, redness of eyes }\end{array}$ & $22 / 25$ & $0.9: 1 / 0.8: 1$ & PL -ve ; 6/18 & p.G122A (H), p.P370L (h), \\
\hline $\mathrm{P} 13$ & Heaviness of Forehead, watering, redness of eyes & $27 / 19$ & $0.7: 1 / 0.5: 1$ & $6 / 12 ; 6 / 6$ & p.R136I (h), p.K484= (h) \\
\hline P14 & Heaviness of forehead, Vision loss & $24 / 20$ & $0.8: 1 / 0.8: 1$ & $6 / 9 ; 6 / 18$ & p.K484= (h) \\
\hline P15 & Heaviness of forehead, Vision loss & $22 / 22$ & $0.7: 1 / 0.7: 1$ & $6 / 60 ; 6 / 60$ & -- \\
\hline P16 & Watering in eyes, Severe vision loss in both eyes & $49 / 38$ & $0.9: 1 / 0.7: 1$ & PL-ve； $6 / 36$ & -- \\
\hline $\mathrm{P} 17$ & vision loss in both eyes & $30 / 30$ & $0.7: 1 / 0.7: 1$ & $6 / 12 ; 6 / 9$ & p.K484= (h) \\
\hline P18 & Heaviness of Forehead, redness of eyes, severe vision loss & $35.8 / 14.3$ & Opaque media/0.8:1 & PL+； $6 / 6$ & -- \\
\hline P19 & Heaviness of forehead, Vision loss & $36 / 40$ & $0.8: 1 / \mathrm{TC}$ & $6 / 18 ; \quad \mathrm{HM}$ & p.R76K (H), p.K484= (h) \\
\hline $\mathrm{P} 20$ & Heaviness of Forehead, redness of eyes, watering in eyes & $24 / 12$ & $0.8: 1 / 0.5: 1$ & $6 / 6 \mathrm{OU}$ & p.R76K (h), p.K484= (h) \\
\hline $\mathrm{P} 21$ & Heaviness of Forehead & $23 / 23$ & $0.6: 1 / 0.6: 1$ & 6/6; OU & p.K484= (h) \\
\hline $\mathrm{P} 22$ & Vision loss & $23 / 23$ & $0.6: 1 / 0.9: 1$ & $6 / 9 ; \mathrm{HM}$ & p.R76K (H) \\
\hline $\mathrm{P} 23$ & Heaviness of forehead, Redness of eyes & $18.9 / 23.8$ & $0.7: 1 / 0.7: 1$ & $6 / 9 ; 6 / 9$ & p.R76K (H), p.K484= (h) \\
\hline $\mathrm{P} 24$ & Pain in eyes & $13.4 / 14.6$ & $0.8: 1 / 0.7: 1$ & $6 / 6 ; 6 / 6$ & p.S238N (h) \\
\hline $\mathrm{P} 25$ & Heaviness of Forehead, vision loss & $20 / 28$ & $0.7: 1 / 0.7: 1$ & $6 / 12 ; 6 / 18$ & p.K484= (h) \\
\hline $\mathrm{P} 26$ & Heaviness of Forehead, watering in eyes & $22 / 20$ & $0.7: 1 / 0.7: 1$ & $6 / 9 ; \mathrm{OU}$ & p.R76K $(\mathrm{H})$, p.K484= $(\mathrm{H})$ \\
\hline P27 & Heaviness of Forehead, vision loss & $10.2 / 14.6$ & $\mathrm{HC} / 0.68: 1$ & $6 / 18 ; 6 / 24$ & p.R76K (H), p.K484= (h) \\
\hline $\mathrm{P} 28$ & Heaviness of Forehead & $22 / 20$ & $0.7: 1 / 0.7: 1$ & $6 / 18 ; 6 / 18$ & p.Q48H (h), p.R76K $(H), \quad$ p.K484= (h) \\
\hline P29 & Pain in eyes, sudden blindness some times for few seconds & $12.2 / 17.3$ & $0.8: 1 / 0.8: 1$ & $6 / 9$ OU & -- \\
\hline P30 & Heaviness of Forehead, redness of eyes & $22 / 24$ & $0.7: 1 / 0.6: 1$ & $6 / 12 \mathrm{OU}$ & p.K484= (h) \\
\hline P31 & Heaviness of Forehead & $26 / 14$ & $0.6: 1 / 0.5: 1$ & $6 / 6 \mathrm{OU}$ & p.K484= (h) \\
\hline P32 & Vision loss & $27 / 24$ & $0.9: 1 / 0.9: 1$ & PL-ve ; FC & p.K484= (h) \\
\hline P33 & Heaviness of Forehead, watering in eyes & $26 / 20$ & $0.8: 1 / 0.4: 1$ & $6 / 36 ; 6 / 18$ & -- \\
\hline P34 & Heaviness of Forehead & $24 / 27$ & $0.6: 1 / 0.7: 1$ & $6 / 6$ OU & p.K484= (h) \\
\hline P35 & Vision problem during night driving & $22 / 22$ & $0.7: 1 / 0.4: 1$ & $6 / 12 ; 6 / 9$ & -- \\
\hline P36 & Heaviness of Forehead, watering in eyes, vision problems & $28 / 28$ & $0.4: 1 / 0.7: 1$ & $6 / 24 ; 6 / 60$ & $\begin{array}{l}\text { p.R76K }(H), p . S 238 N(h), p . R 422 H(h), p . K 484= \\
(h),\end{array}$ \\
\hline P37 & Watering in eyes, vision problems & $28 / 14$ & $0.9: 1 / 0.3: 1$ & $6 / 36 ; \quad 6 / 18$ & p.E14= (h) \\
\hline P38 & Heaviness of Forehead & $25 / 24$ & $0.6: 1 / 0.7: 1$ & $6 / 6 \mathrm{OU}$ & p.E14=(h), p.K484= (h) \\
\hline P39 & Vision loss, halos around light & $14.6 / 15.9$ & $0.6: 1 / 0.5: 1$ & $6 / 9 ; 6 / 6$ & p.R76K (h), p.E14= (h), p.K156K (h), p.K484= (h) \\
\hline $\mathrm{P} 40$ & Heaviness of Forehead, Vision loss & $12 / 12$ & $0.7: 1 / 0.8: 1$ & $6 / 6 ; 6 / 9$ & p.R76K (h), p.K484= (h) \\
\hline $\mathrm{P} 41$ & Vision loss, watering in eyes & $26 / 26$ & $0.8: 1 / 0.8: 1$ & $5 / 60 ; 3 / 60$ & p.K484= (h) \\
\hline $\mathrm{P} 42$ & Halos around light, scattered vision & $28 / 22$ & $0.8: 1 / 0.8: 1$ & $6 / 36 \mathrm{OU}$ & p.P370L (h), p.K484= (h) \\
\hline $\mathrm{P} 43$ & Pain and watering in the yes & $26 / 22$ & $0.6: 1 / 0.6: 1$ & $6 / 6 \mathrm{OU}$ & p.K484= $(\mathrm{H})$ \\
\hline $\mathrm{P} 44$ & Pain in eyes, vision loss & $17 / 28$ & $0.5: 1 / 0.9: 1$ & $6 / 6 ; \mathrm{PL}+$ & p.K484= (h) \\
\hline $\mathrm{P} 45$ & Redness of eyes, watering, vision problem & $25 / 20$ & $0.7: 1 / 0.7: 1$ & $6 / 36 ; 6 / 18$ & p.R76K (h), p.S173T (h), p.R200Kfs*16/p.L215X, \\
\hline P46 & Headache & $25 / 23$ & $0.8: 1 / 0.7: 1$ & $6 / 9 ; 6 / 9$ & -- \\
\hline $\mathrm{P} 47$ & Vision loss in left eye, watering & $17.3 / 18.6$ & $0.7: 1 / 0.8: 1$ & $6 / 9 ; \mathrm{HM}$ & p.K484= (H) \\
\hline $\mathrm{P} 48$ & Watering in eyes, vision problems & $21 / 26$ & $0.8: 1 / 0.8: 1$ & $6 / 9 ; 6 / 18$ & p.K484= (H) \\
\hline P49 & Vision problems & Soft eye/25 & Hazy cornea OU & $6 / 60 ; 6 / 36$ & p.K484= (h) \\
\hline $\mathrm{P} 50$ & Watering in eyes, vision loss & $17.3 / 30.4$ & $0.7: 1 / 0.8: 1$ & $6 / 9 ; \mathrm{FC}$ & p.K484=(h) \\
\hline P51 & Blurred vision, Watering in eyes, heaviness of forehead & $23.5 / 16$ & $0.5: 1 / 0.7: 1$ & $6 / 12 ; 6 / 6$ & p.R76K (h) \\
\hline P52 & Watering in eyes, heaviness of forehead & $22 / 17.8$ & $0.6: 1 / 0.7: 1$ & $6 / 18 ; 6 / 12$ & p.K484= (h) \\
\hline P53 & Watering in eyes, heaviness of forehead & $16 / 22.4$ & $0.7: 1 / 0.7: 1$ & $6 / 18 ; 6 / 6$ & p.R76K $(\mathrm{H})$ \\
\hline P54 & Hazy cornea, Watering in eyes, hea dache & $23.6 / 14.3$ & $0.8: 1 / 0.5: 1$ & $6 / 24 ; 6 / 36$ & p.Q19K (h) \\
\hline P55 & Redness of eyes, headache & $21 / 23$ & $0.6: 1 / 0.7: 1$ & $6 / 12 ; 6 / 6$ & -- \\
\hline P56 & Redness of eyes, heaviness of forehead & $24.6 / 20.6$ & $0.8: 1 / 0.6: 1$ & $6 / 36 ; 6 / 18$ & -- \\
\hline P57 & Pain in both eyes & $23.2 / 19$ & TC/0.6:1 & $6 / 36 ; 6 / 6$ & -- \\
\hline P58 & Pain in right eye, Heaviness of Forehead & $23 / 15.9$ & $0.6: 1 / 0.6: 1$ & $6 / 6 ; 6 / 6$ & -- \\
\hline P59 & Hazy cornea, Pain in eyes, Heaviness of Forehead & $28 / 20$ & $0.8 / 0.8$ & $6 / 36 ; 6 / 12$ & -- \\
\hline $\mathrm{P} 60$ & Slight pain and irritation in eyes, Heaviness of Forehead & $22.3 / 17.3$ & $0.5: 1 / 0.7: 1$ & $6 / 6 ; 6 / 6$ & -- \\
\hline P61 & Headache, No vision in right eye & $15.9 / 24.6$ & $0.5: 1 / 0.7: 1$ & PL -ve; $6 / 18$ & p.R76K (h); p.F430= \\
\hline P62 & No vision in left eye, headache & $17.7 / 8.8$ & $0.5: 1 / \mathrm{TC}$ & $6 / 18 ;$ PL -ve & \\
\hline P63 & Headache, watering in eyes & $20.6 / 24.4$ & $0.7: 1 / 0.6: 1$ & $6 / 6 ; 6 / 6$ & p.R76K (h) \\
\hline $\mathrm{P} 64$ & Pain in eyes & $26.1 / 22.3$ & $0.7: 1 / 0.8: 1$ & $6 / 12 ; 6 / 12$ & p.R76K (h) \\
\hline P65 & Redness and pain in eyes & $22.4 / 18.9$ & $0.5: 1 / 0.6: 1$ & $6 / 18 ; 6 / 18$ & p.R76K (h) \\
\hline P66 & Heaviness of forehead & $20.6 / 28$ & $0.7: 1 / 0.7: 1$ & $6 / 6 ; 6 / 24$ & \\
\hline P67 & Hazy cornea, Heaviness of forehead & $22.9 / 17.3$ & $0.5: 1 / 0.6: 1$ & $6 / 6 ; 6 / 12$ & p.R76K (h); p.Y347=; \\
\hline P68 & Redness of eyes, Heaviness of forehead & $15 / 22.7$ & $0.7: 1 / 0.5: 1$ & $6 / 12 ; 6 / 18$ & p.R76K (H) \\
\hline P69 & Pain in eyes & $23.6 / 18.9$ & $0.6: 1 / 0.5: 1$ & $6 / 12 ; 6 / 36$ & p.R76K (h) \\
\hline
\end{tabular}




\begin{tabular}{|c|c|c|c|c|c|}
\hline P70 & Redness or eyes & 17.3/23.3 & $0.7: 1 / 0.7: 1$ & $6 / 36 ; 6 / 36$ & p.R76K (h) \\
\hline P71 & Watering in eyes, pain in eyes, heaviness of forehead & $20.6 / 28.6$ & $0.6: 1 / 0.4: 1$ & $6 / 9 ; 6 / 24$ & p.R76K (h) \\
\hline P72 & Redness of eyes, heaviness of forehead & $17.3 / 25.8$ & $0.8: 1 / 0.5: 1$ & $6 / 9 ; 6 / 9$ & -- \\
\hline P73 & $\begin{array}{l}\text { Hazy cornea, watering in eyes, redness of eyes and pain in } \\
\text { eyes }\end{array}$ & $20 / 24.6$ & $0.8: 1 / 0.6: 1$ & FC; $6 / 24$ & -- \\
\hline P74 & Redness of eyes, watering in eyes, heaviness of forehead & $17.3 / 22.9$ & $0.8: 1 / 0.7: 1$ & $6 / 6 ; 6 / 6$ & -- \\
\hline P75 & Hazy cornea left eye & $14.6 / 30.4$ & $0.5: 1 / 0.7: 1$ & $6 / 6 ; 6 / 12$ & -- \\
\hline P76 & Pain in right eye & $25.4 / 19$ & $0.7: 1 / 0.5: 1$ & $6 / 36 ; 6 / 6$ & -- \\
\hline P77 & Problem in sunlight & $25 / 25$ & $0.4: 1 / 0.7: 1$ & $6 / 6 ; 6 / 6$ & -- \\
\hline P78 & Low vision & $24.2 / 17.3$ & $0.8: 1 / 0.8: 1$ & $6 / 6 ; 6 / 6$ & -- \\
\hline P79 & Redness of eyes & $17.3 / 20.6$ & TC /0.8:1 & PL +ve; 6/9 & -- \\
\hline P80 & heaviness of forehead, Vision problems & $26 / 25$ & $0.6: 1 / 0.6: 1$ & $6 / 36 ; 6 / 36$ & -- \\
\hline
\end{tabular}

Note:

3’UTR: 3' Untranslated Region

MYOC sequence variants in Untranslated Regions, intrones has not been considered

H: Homozygous h: heterozygous Rt: Right eye Lt: Left Eye OU: Both Eyes NS: Normal Shifting

TC: Total cupping HC: Hazy Corneal Media NS: Normal Shifting HM: Hand movement FC: Finger Counting PL-ve: No perception of light

Red Color: Pathogenic variant

Blue Color: not sure about the pathogenicity

Green Color: Non-pathogenic variant

Table3: Identified sequence variants and pathogenicity predictions of missense variants

\begin{tabular}{|c|c|c|c|c|c|c|c|c|c|c|c|c|c|}
\hline \multirow{2}{*}{$\begin{array}{l}\text { Sr. } \\
\text { No. }\end{array}$} & \multirow[t]{2}{*}{ Identified Change } & \multirow{2}{*}{$\begin{array}{l}\text { Genomic Position } \\
\text { \& Base Change }\end{array}$} & \multirow{2}{*}{$\begin{array}{l}\text { cDNA } \\
\text { position }\end{array}$} & \multirow{2}{*}{$\begin{array}{l}\text { Codon } \\
\text { Change }\end{array}$} & \multirow{2}{*}{$\begin{array}{l}\text { Amino Acid } \\
\text { Change }\end{array}$} & \multirow{2}{*}{$\begin{array}{l}\text { No. of } \\
\text { Patients with } \\
\text { the change } \\
\text { (H: } \\
\text { homozygous } \\
\text { h: } \\
\text { heterozygous) }\end{array}$} & \multirow{2}{*}{$\begin{array}{l}\text { Present } \\
\text { in } \\
\text { controls } \\
\text { or not }\end{array}$} & \multirow{2}{*}{$\begin{array}{l}\text { Presence } \\
\text { in } \\
\text { gnomAD } \\
\text { Database }\end{array}$} & \multirow{2}{*}{$\begin{array}{l}\text { Presence } \\
\text { in } \\
\text { ClinVar } \\
\text { Database }\end{array}$} & \multicolumn{4}{|c|}{ Pathogenicity Predictions } \\
\hline & & & & & & & & & & SIFT & PROVEAN & PolyPhen2 & $\begin{array}{r}\text { Mutati } \\
\text { Taste }\end{array}$ \\
\hline 1 & p.Glu14= & g.171652570G >A & c. 42 & GAG>GAA & p.E14= & $03(\mathrm{~h})$ & No & Yes & No & \multicolumn{4}{|c|}{ Not Applicable } \\
\hline 2 & p.Gln19Lys & g.171652557C>A & c.55 & CAG>AAG & p.Q19K & 01(h) & No & No & No & tolerated & neutral & benign & polymorp \\
\hline 3 & p.Gln48His & g.171652468G > T & c.144 & CAG $>$ CAT & p.Q48H & $01(\mathrm{~h})$ & No & Yes & Yes & tolerated & neutral & benign & $\begin{array}{l}\text { disease- } \\
\text { causing }\end{array}$ \\
\hline 4 & p.Arg 76Lys & g.171652385G>A & c.227 & AGA $>$ AAA & p.R76K & $11(\mathrm{H}), 13(\mathrm{~h})$ & Yes & Yes & Yes & $\begin{array}{l}\text { not } \\
\text { tolerated }\end{array}$ & Neutral & benign & polymorp \\
\hline 5 & p.Gly122Ala & g.171652247G>C & c.365 & GGC>GCC & p.G122A & $01(\mathrm{H})$ & No & No & No & tolerated & Neutral & \begin{tabular}{|l|} 
benign \\
\end{tabular} & polymorp \\
\hline 6 & p.Arg136Ile & g.171652205G>T & c.407 & AGA $>$ ATA & p.R136I & $01(\mathrm{~h})$ & No & No & No & $\begin{array}{l}\text { not } \\
\text { tolerated }\end{array}$ & neutral & benign & $\overline{\text { polymorp }}$ \\
\hline 8 & p.Ser173Thr & g.171652094G>C & c.518 & AGC $>$ ACC & p.S173T & $01(\mathrm{~h})$ & No & No & No & tolerated & neutral & $\begin{array}{l}\text { possibly } \\
\text { damaging }\end{array}$ & $\overline{\text { polymorp }}$ \\
\hline 9 & $\begin{array}{l}\text { p.Arg 200Lysfs*15 } \\
\text { or } \\
\text { p.Arg 200Lys Ter*15 }\end{array}$ & g.171652013delG & c.599 & $\begin{array}{l}\text { Frameshift } \\
\text { mutation }\end{array}$ & p.R200KTer*15 & $01(\mathrm{H})$ & No & No & No & \multicolumn{4}{|c|}{ Not Applicable } \\
\hline 10 & \multirow[t]{2}{*}{$\begin{array}{c}\text { p.[(Leu215Pro; } \\
\text { Lys216Ile)] }\end{array}$} & \multirow{2}{*}{$\begin{array}{l}\text { g.171607823T }>C, \\
\text { g.171607822G }>C, \\
\text { g.171607820A }>\text { T, } \\
\text { g.171607819G }>\text { T }\end{array}$} & $\begin{array}{l}\text { c. } 644 \\
\text { c. } 645\end{array}$ & $\mathrm{CTG}>\mathrm{CCC}$ & \multirow[t]{2}{*}{$\begin{array}{l}\text { p. } \\
{[(\text { L215P;K216I)] }}\end{array}$} & \multirow{2}{*}{$\begin{array}{l}01(\mathrm{~h}) \\
\text { As compound } \\
\text { heterozygous }\end{array}$} & No & Yes & No & $\begin{array}{l}\text { not } \\
\text { tolerated }\end{array}$ & deleterious & $\begin{array}{l}\text { probably } \\
\text { damaging }\end{array}$ & $\begin{array}{l}\text { disease- } \\
\text { causing }\end{array}$ \\
\hline 11 & & & $\begin{array}{l}\text { c. } 647 \\
\text { c. } 648\end{array}$ & AAG $>$ ATT & & & No & No & No & $\begin{array}{l}\text { not } \\
\text { tolerated }\end{array}$ & \begin{tabular}{|l|} 
deleterious \\
\end{tabular} & $\begin{array}{l}\text { probably } \\
\text { damaging }\end{array}$ & $\begin{array}{l}\text { disease- } \\
\text { causing }\end{array}$ \\
\hline 12 & p.Ser238Asn & g.171638614G>A & c.713 & AGT $>$ AAT & p.S238N & $02(\mathrm{H})$ & No & No & No & tolerated & neutral & benign & $\overline{\text { polymorp }}$ \\
\hline 13 & p.Tyr347= & g.171636399T >C & c.1041 & TAT>TAC & p.Y347= & 01(h) & No & & & \multicolumn{4}{|c|}{ Not Applicable } \\
\hline 14 & p.Pro370Leu & g.171605471C>T & c.1109 & CCG $>$ CTG & p.P370L & $03(\mathrm{~h})$ & No & No & Yes & $\begin{array}{l}\text { not } \\
\text { tolerated }\end{array}$ & deleterious & $\begin{array}{l}\text { probably } \\
\text { damaging }\end{array}$ & $\begin{array}{l}\text { disease- } \\
\text { causing }\end{array}$ \\
\hline 15 & p.Arg $422 \mathrm{His}$ & g.171636175G >A & c.1265 & CGT $>$ CAT & p.R422H & $01(\mathrm{~h})$ & No & Yes & No & tolerated & neutral & $\begin{array}{l}\text { probably } \\
\text { damaging }\end{array}$ & $\begin{array}{l}\text { disease- } \\
\text { causing }\end{array}$ \\
\hline
\end{tabular}

\section{Figures}




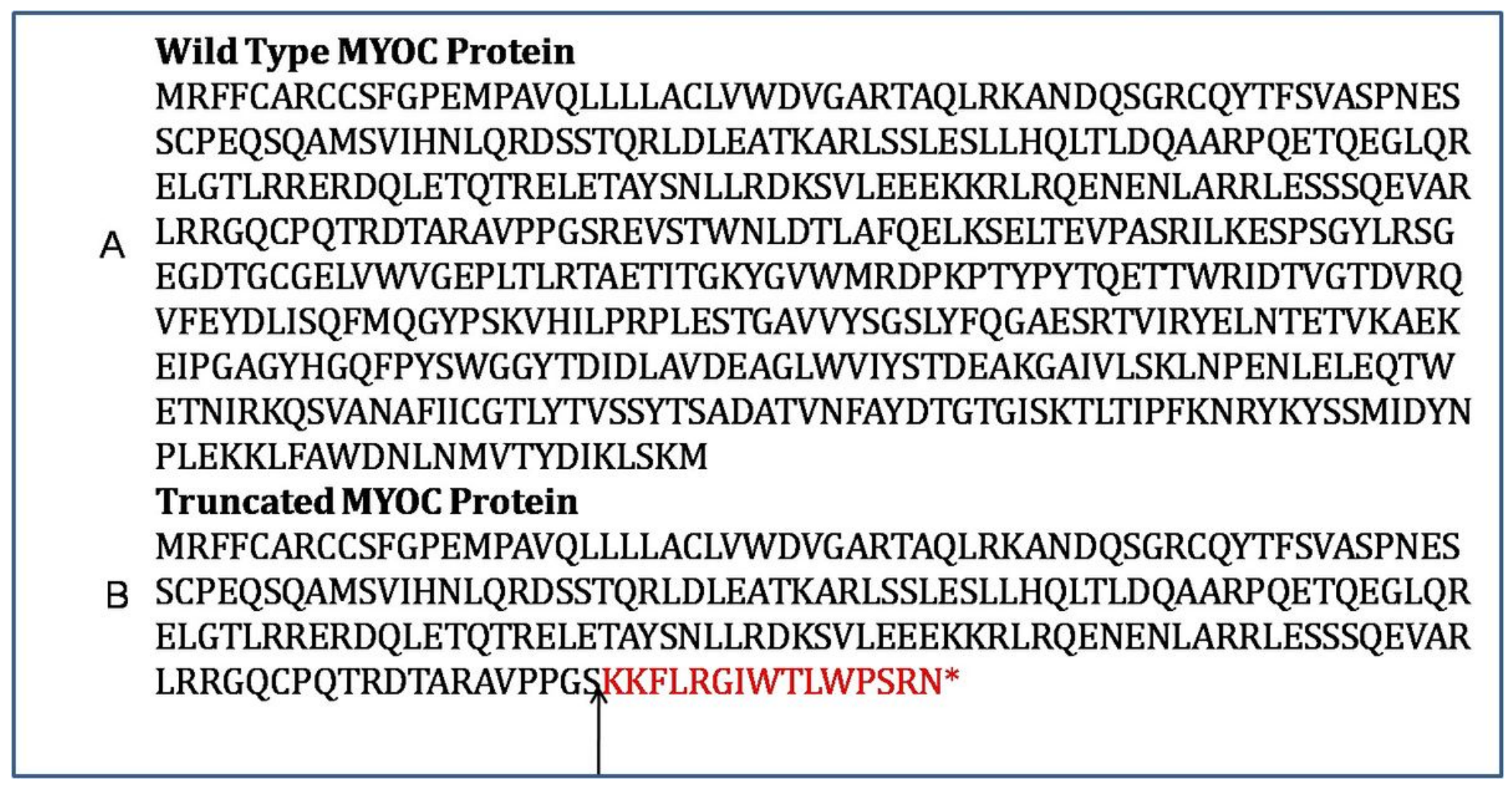

Figure 1

Showing amino acid sequence of human myocilin protein A: Wild-type MYOC protein. B: Truncated MYOC protein of 214 amino acids (black arrow shows the position after which frameshift occurs and red letters show amino acids after frameshift). 


\begin{tabular}{|c|c|c|c|c|c|c|}
\hline Chimpanzee & $\begin{array}{c}Q 48 \mathrm{H} \\
\downarrow \\
\text { SGRCH }{ }_{\mathrm{H}} \mathrm{YTFSVA}\end{array}$ & $\begin{array}{c}\text { R76K } \\
\downarrow \\
\text { SVIHNLC RDSST }\end{array}$ & \multicolumn{2}{|l|}{$\underset{\downarrow}{\mathrm{G} 12 \mathrm{~A}}$} & $\begin{array}{c}\text { R136I } \\
\downarrow \\
\text { LETOI RELETAY }\end{array}$ & $\begin{array}{c}S 173 T \\
\downarrow \\
\text { RRLESSSSOEVAR }\end{array}$ \\
\hline Gorilla & SGRCOYTFSVA & SVIHNLQRDSST & \multicolumn{2}{|c|}{ ELGTLRQERDQL } & LETQTRELETAY & RRLESSSQEVAR \\
\hline Human & SGRCOYTFSVA & SVIHNLCRPSST & \multicolumn{2}{|c|}{ ELGTLRRERDQL } & LETQTRELETAY & RRLESSSQEVAR \\
\hline Orangutan & SGRCOYTFSVV & SVIRNLCRDSST & \multicolumn{2}{|c|}{ ELGTLRRERDQL } & LETQTRELETAY & RRLESSSQEVAR \\
\hline Macaque & SGRCOYTFSVA & SVIHNLCKDSST & \multicolumn{2}{|c|}{ ELGTLRRERDQL } & LETQTRELETAY & RRLESSSQEVAR \\
\hline Bolivian squirrel & NGRCOYTFSVA & SVIHNLCRDSST & \multicolumn{2}{|c|}{ ELGTLKQERDQL } & LEAQTRELETAY & RRLESSSQEVAR \\
\hline Naked_Mole-rat & SGWCOYTFTVA & LAIQDLQRPSST & \multicolumn{2}{|c|}{ ELGTLRRDRDRL } & LETEARELEVAY & RRLESSSQEVAR \\
\hline Guinea_Pig & SGRCOYTFSVA & SAIQDLQRDSSS & \multicolumn{2}{|c|}{ ELGALRKDRDRL } & LETQARELEVAY & RRLESSSQEAAR \\
\hline Mouse & SGRCOYTFTVA & SAIQDLQRPSSI & \multicolumn{2}{|c|}{ QLGALRRERDQL } & LETQTRDLEAAY & RRLESSSEEVTR \\
\hline Rabbit & SGRCOYTFSVA & SAIQDLCRDSST & \multicolumn{2}{|c|}{ ELGTLRRERDQL } & LESQTRELEEAYY & RRLESSSQEVAR \\
\hline Cow & SGRCOYTFSVA & LAIQELCRDSSE & \multicolumn{2}{|c|}{ ELEALRREREQL } & LETQTIOELESAY & RRLESSSQEVAS \\
\hline Sheep & SGRCOYTFSVA & SAIQELQRESSE & \multicolumn{2}{|c|}{ ELEALRREREQL } & LETQTRELESAY & RRLESSSQEVAS \\
\hline Horse & SGRCOYTFSVA & SAIQDLQRPSST & \multicolumn{2}{|c|}{ ELDTLRRERDQL } & LETQTRELETAY & RRLESSSQEVAR \\
\hline Tiger & SGRCQYTFSVA & SAIQDLQRDSSA & \multicolumn{2}{|c|}{ ELGALRREQEQL } & LESQN RELEASY & RRLDSSSQEVAR \\
\hline Cat & 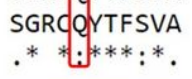 & $\begin{array}{l}\text { SAIQDLQRPSSA } \\
.^{*}::^{* *}::^{* *}\end{array}$ & \multicolumn{2}{|c|}{ ELGALRREREQL } & $\begin{array}{l}\text { LESQN RELEASY } \\
* *:: \text { : }: * *:^{*}\end{array}$ & $\begin{array}{l}\text { RRLDSSSQEVAR } \\
* * *: * * *: .:\end{array}$ \\
\hline & \multicolumn{2}{|c|}{$\begin{array}{c}\text { L215P \& K216I } \\
\downarrow \downarrow\end{array}$} & \multicolumn{2}{|l|}{$\begin{array}{c}\text { S238N } \\
\downarrow\end{array}$} & & $\mathrm{R} 422 \mathrm{H}$ \\
\hline Chimpanzee & \multicolumn{3}{|c|}{ TLAFQELKSELTEVPVSRILKESPSGYLRS' } & \multicolumn{2}{|c|}{ IPGAGYHGQPPYSWGGY } & NIRKQSVANAF \\
\hline Gorilla & \multicolumn{3}{|c|}{ TLAFQELKSELTEVPASRILKESPSGYLRS $\bar{G}$} & \multicolumn{2}{|c|}{ IPGAGYHGQFPYSWGGY } & NIRKQSVANAF \\
\hline Human & \multicolumn{3}{|c|}{ TLAFQELKSELTEVPASRILKESPSGYLRSG } & \multicolumn{2}{|c|}{ IPGAGYHGQFPYSWGGY } & NIRKQSVANAF \\
\hline Orangutan & \multicolumn{3}{|c|}{ TLAFQELKSKLTEVPASRILKESPSGYLRSR } & \multicolumn{2}{|c|}{ IPGAGYHGOAPYSWGGY } & NIRKQSVANAF \\
\hline Macaque & \multicolumn{3}{|c|}{ TLAFQELKSELTEVPASRILKESPSGHLOSR } & \multicolumn{2}{|c|}{ IPGAGYHGOAPVSWGGY } & NIRKQSVANAF \\
\hline Bolivian_squirrel & \multicolumn{3}{|c|}{1 TLAFQELKSELTEVPASRILKESPSGHLRSG } & IPGA & GYHGQPPYSWGGY & NIRKQSVANAF \\
\hline Naked_Mole-rat & SLAFQELKSE & TEVPASRILE -SP & SGRPRTE & IPGA & GYHGQPPYSWGGY & NIRKQSVANAF \\
\hline Guineā_Pig & NLAFQELKSE & TEVPASGILQESP & SDRPRIG & IPGA & GYHGQPPYSWGGY & NIRKQSVANAF \\
\hline Mouse & TLAFQELKSE & TEVPASQILKENP & SGRPRSK & IPGA & GYHGHAPYAWGGY & NIRKQSVANAF \\
\hline Rabbit & TLAFQELKSE & TEVPASRILKENP & PVLPRGE & IPGA & GYRGQPPYSWGGY & NIRKQSVANAF \\
\hline Cow & NMDFQELKSE & TEVPASQILKESP & SGHPRNE & IPGA & GYHGQPPYSWGGY & NIRKQSVANAF \\
\hline Sheep & NVDFQELKSE & TEVPASQILKESP & SGHPRNE & IPGA & GYHGQFPYSWGGY & NIRKQSVANAF \\
\hline Horse & NVAFQELKSE & TEVRASERLKESP & SGVPRSE & LPGA & GYHGQPPYSWGGY & NIRKQSVANAF \\
\hline Tiger & TVNFQELKSE & TEVPASRILKESP & SGHPRSE & IPGA & GYHGQPPYSWGGY & NIRKQSVANAF \\
\hline Cat & TVNFQELKSE & TEVPASRILKESP & SGHPRSE & IPGA & GYHGQPPYSWGGY & NIRKQSVANAF \\
\hline & $* * * *$ & $* * \quad * \quad *:$ & & & $* *: *: * * *: * * * *$ & $* * * * * * * * * * *$ \\
\hline
\end{tabular}

Figure 2

a: Multi sequence alignment of the human MYOC protein with the protein from different species Arrow indicates the position of mutated amino acids at position 48, 76, 122,136 and 173. b: Multi sequence alignment of the human MYOC protein with the protein from different species. Arrow indicates the position of mutated amino acids at position $215,216,238,370$ and 422

\section{Supplementary Files}

This is a list of supplementary files associated with this preprint. Click to download.

- SupplementaryFileforDNAseqChromatogramsandpedigree.pdf 